Robert Pawlusiński

https://orcid.org/0000-0002-5924-0741

robert.pawlusinski@uj.edu.pl

Kamil Mróz

https://orcid.org/0000-0001-5978-1604 mrozk123@gmail.com

Marek Grochowicz

https://orcid.org/0000-0002-5766-3847

marek.grochowicz@doctoral.uj.edu.pl

Uniwersytet Jagielloński w Krakowie

Instytut Geografii i Gospodarki Przestrzennej

\title{
ROZWÓJ GOSPODARKI NOCNEJ W MIASTACH HISTORYCZNYCH - ASPEKTY PRZESTRZENNE I FUNKCJONALNE PRZYKŁAD KRAKOWSKIEJ DZIELNICY KAZIMIERZ
}

\begin{abstract}
Abstrakt: Miasta historyczne stanowią szczególną kategorię ośrodków miejskich w Polsce, a z uwagi na potencjał kulturowy ważnym kierunkiem ich rozwoju staje się współcześnie turystyka i sektory z nią powiązane. Jednym z takich sektorów jest Łzw. gospodarka nocna (ang. night-time economy, w skrócie NTE) identyfikowana na podstawie kryterium dostępności czasowej (21:00-5:00) i kryterium funkcjonalnego (jako ogół działalności zaspokajających szeroko rozumiane potrzeby wolnoczasowe ludzi poza ich domem w porze nocnej). Celem artykułu jest charakterystyka gospodarki nocnej w historycznej dzielnicy śródmiejskiej Krakowa - Kazimierzu. Autorzy, opierając się na przeprowadzonej w 2019 r. inwentaryzacji terenowej oraz wywiadach z przedstawicielami lokalnej społeczności, zobrazowali przestrzenne i funkcjonalne aspekty tego zjawiska.
\end{abstract}

Słowa kluczowe: miasto historyczne, gospodarka nocna, nocturnal city, Polska.

\section{SPATIAL AND FUNCTIONAL ASPECTS OF THE NIGHT-TIME ECONOMY IN HISTORIC CITIES: A CASE STUDY OF THE KAZIMIERZ DISTRICT (KRAKÓW, POLAND)}

\begin{abstract}
Historic cities constitute a special category of urban area in Poland. Due to their cultural potential, tourism and related sectors are currently becoming an important development direction. One such sector is their night-time economy, identified on the basis of a time criterion (21:00-5:00), and a functional criterion (understood as all activities that meet people's broad leisure needs outside their home during the night). The aim of the article is to describe the night-time economy in one historical central district of Kraków - Kazimierz. The authors, based on a field inventory conducted in 2019, and interviews with representatives of the local community, have illustrated the spatial and functional aspects of this phenomenon.
\end{abstract}

Keywords: historic city, night-time economy, nocturnal city, Poland.

\section{WPROWADZENIE}

W studiach nad rozwojem gospodarki nocnej szczególne miejsce przypada miastom historycznym, które $\mathrm{z}$ uwagi na posiadane dziedzictwo kulturowe predysponowane są do rozwoju turystycznego (Ashworth, Turnbridge, 2000, 2004; Cohen-Hattab, 2004; Faracik, 2007). Funkcja turystyczna w powiązaniu $\mathrm{z}$ innymi funkcjami tych miast (m.in. akademicka, kulturalna, handlową) stwarza dogodne warunki do rozwoju życia nocnego oraz jego rynkowej emanacji - tj. gospodarki nocnej (Nofre, Giordano, Eldridge, Martins, 2017; Pawlusiński, Zmyślony, 2018; Shaw, 2014; Zmyślony, Pawlusiński, 2020). Przestrzennym wymiarem tego zjawiska są strefy (kwartały) rozrywki nocnej. Można spotkać różne układy przestrzenne gospodarki nocnej w miastach historycznych - czasami strefa ta nakłada się na tzw. centralną dzielnicę turystyczna, $w$ innych 
przypadkach lokalizuje się na obszarach sąsiadujących z centrum - m.in. w dawnych strefach przemysłowych (np. „100cznia” w Gdańsku, „Dolne Młyny” w Krakowie, Nocny Market na terenie dawnego dworca Warszawa Główna), na waterfrontach (Donauinsel w Wiedniu) czy w historycznych dzielnicach miast o dużym potencjale kulturowym (Erzsébetváros w Budapeszcie, Zatybrze w Rzymie). Przykładem takiej strefy jest krakowski Kazimierz - kiedyś odrębne miasto, a obecnie część Dzielnicy I Stare Miasto, który od lat 90. XX w. przeżywa boom turystyczny. Obecnie na terenie tej części miasta - o powierzchni zaledwie 1 kilometra kwadratowego - znajduje się ponad 100 obiektów noclegowych oraz około 350 placówek gastronomicznych i gastronomiczno-rozrywkowych.

Celem artykułu jest charakterystyka funkcjonowania gospodarki nocnej na obszarze Kazimierza, ze szczególnym uwzględnieniem aspektu dostępności czasowej obiektów, ich funkcji, a także wpływu gospodarki nocnej na codzienne życie mieszkańców tej części Krakowa. Do realizacji tego celu wykorzystano wyniki badań terenowych, które objęły inwentaryzację obiektów szeroko rozumianej gospodarki nocnej, obserwację terenową oraz wywiady swobodne z przedstawicielami lokalnej społeczności. Badania przeprowadzono w pierwszej połowie 2019 r. Materiał uzupełniający stanowiły artykuły prasowe, odnoszące się głównie do problematyki życia nocnego prowadzonego na Kazimierzu.

\section{GOSPODARKA NOCNA JAKO PRZEDMIOT STUDIÓW MIEJSKICH}

Gospodarka nocna nie stanowi odrębnego elementu gospodarki miejskiej, ale przenika przez jej różne sektory i jest widoczna we wszystkich formach aktywności człowieka (Pawlusiński, Zmyślony, 2018; Roberts, Eldridge, 2009). Podstawowym kryterium wyodrębnienia gospodarki nocnej jest kryterium czasowe. Najczęściej przyjmowane ramy czasowe dla gospodarki nocnej to okres pomiędzy godziną 20:00/21:00/22:00 a 5:00/6:00/7:00, niekiedy, np. w studiach na temat NTE $\mathrm{w}$ Londynie, za porę nocną uznaje się przedział pomiędzy 18:00 a 6:00 (Think Night...). Nie istnieje również jedna powszechnie akceptowana definicja gospodarki nocnej, dotycząca jej zakresu przedmiotowego. Jak zauważa Shaw (2014), termin ten zrodził się na gruncie badań społecznych nad nocnym przemysłem rozrywkowym i jego silnymi związkami z konsumpcją alkoholu. Niektóre z opracowań ujmują gospodarkę nocną znacznie szerzej, zaliczając do niej wszelkie przejawy aktywności społecznej i gospodarczej w mieście nocą (London at night..., 2018).
W zakres przedmiotowy gospodarki nocnej wchodzą przede wszystkim (Pawlusiński, Zmyślony, 2018) (rys. 1): - usługi rozrywkowe oparte na muzyce popularnej i spotkaniach w klubach muzycznych (kluby muzyczne, dyskoteki, kluby taneczne, klubokawiarnie, muzyka plenerowa);

- usługi hazardowe (kasyna, salony gier i in.);

- usługi kulturalne (teatry, kina, filharmonie, sale koncertowe, muzea, galerie, przestrzenie kreatywne);

- usługi związane z organizacją wydarzeń masowych oraz różnego rodzaju spotkań (amfiteatry i sceny miejskie, plenerowe koncerty muzyczne, wydarzenia jubileuszowe-np.imprezy sylwestrowe, teatry uliczne, gry miejskie, masowe wydarzenia sportowe; organizacja spotkań prywatnych w przestrzeniach publicznych i prywatnych - np. w obiektach muzealnych w nocy); - usługi gastronomiczne i gastronomiczno-rozrywkowe (restauracje, kawiarnie, puby, pijalnie alkoholi, ogródki piwne, food-cornery z gastronomią mobilną);

- usługi przewodnictwa i organizacji zwiedzania noca;

- usługi związane z aktywną rekreacją (centra sportowe, siłownie, pływalnie, siłownie plenerowe, boiska sportowe);

- usługi związane z odnową biologiczną (centra spa \& wellness i in.);

- usługi handlowe - związane z działalnością sklepów i centrów handlowych, ale także imprezy okazjonalne, jak jarmarki, wystawy itp.

Do usług towarzyszących, istotnie kształtujących możliwości funkcjonowania gospodarki nocnej należą przede wszystkim:

- usługi publicznego transportu nocnego;

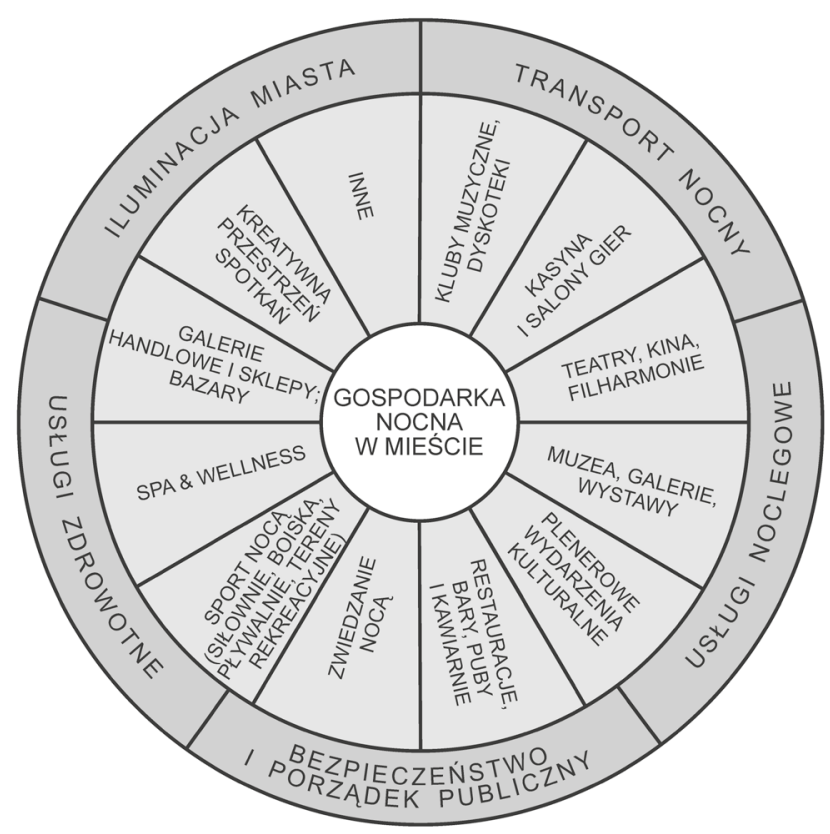

Rysunek 1. Gospodarka nocna miasta - elementy składowe Źródło: opracowanie własne 
- usługi związane z zabezpieczeniem porządku publicznego i bezpieczeństwa;

- usługi noclegowe;

- usługi zdrowotne;

- iluminacja zabytków i ciągów komunikacyjnych w mieście.

Problematyka funkcjonowania miast nocą i jego ekonomicznego wymiaru, określanego mianem gospodarki nocnej miasta, stanowi wciąż nowe pole badawcze w studiach miejskich. Van Liempt, van Aalst i Schwanen (2015) wskazują alegorycznie, że szeroko rozumiane studia miejskie wciąż cierpią na "nyktalopię", bezzasadnie pomijając porę nocną. Za niezbędną uznają odpowiedź na pytanie, jak funkcjonują współczesne miasta nocą (nocturnal cities), tzn. jak są "wytwarzane", „używane”, , doświadczane" i „regulowane" (van Liempt, van Aalst, Schwanen, 2015). Należy podkreślić, że „noc miejska” może być rozpatrywana na różnych płaszczyznach: kulturowej, społecznej, ekonomicznej i przestrzennej (Roberts, Eldrige, 2009).

Pierwsze studia nad rolą nocy i gospodarki nocnej $\mathrm{w}$ miastach były związane $\mathrm{z}$ rewitalizacją miast. Badania z tego zakresu zostały zapoczątkowane w Wielkiej Brytanii już pod koniec lat 80. XX w. przez zespół badawczy Comedia (Bianchini, 1995; Shaw, 2014). Miały one charakter stricte planistyczny i wiązały się z identyfikacją narzędzi wspierających ożywienie miast nocą. Jak zauważają Roberts i Eldrigde (2009), miasta brytyjskie borykały się z problemem deglomeracji ludności z centrów do suburbiów, co w efekcie sprawiało, że były opustoszałe po godzinach pracy. Gospodarka nocna miała być panaceum na przywrócenie życia w centralnych częściach miast. Ideę tę najlepiej obrazuje wypowiedź Bianchiniego, członka Comedii:

[...] istnieje możliwość podwojenia korzyści płynących z funkcjonowania gospodarki miasta w ciągu dnia, poprzez jej rozszerzenie na godziny nocne, poczynając od rozrywki, a następnie uzupełniając ją o inne sektory gospodarki [...]; wielu ludzi pracujących w ciągu dnia może potrzebować dłuższych godzin otwarcia w celu uzyskania dostępu do obiektów miejskich (Bianchini, 1995, s. 125).

Współcześnie dużo uwagi w badaniach nad rozwojem gospodarki nocnej poświęca się analizie stanu jej rozwoju i znaczenia dla systemu lokalnej gospodarki oraz powiązaniom z innymi dziedzinami gospodarki. Punkt wyjścia dla tych badań stanowią raporty na temat "nocy miejskiej", opracowywane dla niektórych miast w Europie (np. Londyn), Australii (Sydney, Melbourne, Perth) czy Ameryce Północnej (Nowy Jork, Los Angeles, Vancouver). Liczne są także prace o charakterze inwentaryzacyjnym, opisujące skalę gospodarki nocnej w poszczególnych miastach świata. W Polsce studia z tego zakresu podejmowali już Iwanicki i Dłużewska $(2018,2015)$. Powiązania gospodarki nocnej z innymi sektorami gospodarki analizowali m.in. Pawlusiński i Zmyślony $(2018,2020)$ oraz Rowe (2008).

Specyfikę gospodarki nocnej w miastach amerykańskich omówili szeroko Campo i Ryan (2008). Autorzy wyróżnili trzy rodzaje oferty nocnej miasta (sophisticated entrantainent, "high end" enterntainment, middlebrow partying), wskazując główne grupy odbiorców oraz strefy, w których można z nich skorzystać. Na szczególną uwagę zasługuje tzw. prosta rozrywka middlebrow partying, która współcześnie zdominowała życie nocne. Jest ona skierowana do klienta masowego i w dużej mierze opiera się na konsumpcji alkoholu. Dla tej grupy konsumentów dedykowane są nowe przestrzenie w miastach, określane przez autorów mianem new enterntainment zones. W przeciwieństwie do stref, w których zlokalizowane są placówki kulturalne (teatry, muzea, sale koncertowe), miejsca te cechuje niska estetyka przestrzeni i tymczasowość (np. poprzez lokalizację w dawnych kwartałach przemysłowych lub zajmowanie zdegradowanych obszarów, nieatrakcyjnych z punktu widzenia innych form życia miejskiego).

Z rozwojem prostej rozrywki wiąże się nierozerwalnie kwestia negatywnych następstw gospodarki nocnej, które są odczuwane przede wszystkim przez mieszkańców. Problematyka ta silnie koresponduje z zagadnieniem gentryfikacji turystycznej (por. Kowalczyk-Anioł, 2019; Kowalczyk-Anioł, Zmyślony, 2017). W ramach szerokiego wachlarza zagadnień wymienić należy nie tylko kwestie zakłóceń ciszy nocnej czy wandalizmu dokonywanego zwłaszcza pod wpływem alkoholu i narkotyków, ale i wzrostu cen nieruchomości oraz produktów i usług na lokalnym rynku. Zagadnienia te poruszane były w odniesieniu do wielu miast europejskich, m.in. Barcelony (Nofre, Giordano, Eldridge, Martins, 2017), Lizbony (Nofre i in., 2018), Budapesztu (Pinke-Sziva, Smith, Olt, Berezvai, 2019) oraz miast brytyjskich (Roberts, 2006). Ważnym wątkiem w tym nurcie badawczym jest kwestia upijania się, m.in. młodzieży (binge drinking), analizowana stosunkowo często wśród badaczy brytyjskich (m.in.: Hadfield, Lister, Traynor, 2009; Sheard, 2011).

Ostatnio wiele prac koncentruje się na problematyce zarządzania życiem nocnym w miastach. A najczęściej dyskutowanym tematem jest kwestia ustanowienia funkcji burmistrza nocnego (Pawlusiński, Zmyślony, 2018). Jak podają Seijas i Gelders (2020), instytucje takie działają już w ponad 40 miastach na świecie, w tym w Pradze i Budapeszcie. Są one różnie umocowane prawnie, niektóre działają $\mathrm{w}$ ramach struktur miejskich (np. w Pradze), inne jako jednostki zewnętrzne (np. Amsterdam), współpracując z władzami miasta. Urząd burmistrza nocnego wciąż nie powstał $\mathrm{w}$ żadnym $\mathrm{z}$ polskich miast, chociaż $\mathrm{w}$ ostatnich miesiącach prowadzone są na ten temat żywe dyskusje w Krakowie oraz w Warszawie (Kursa, 2019; Mikulska, 2018; Radkowski, 2019; Salomon, 2019; Tymczak, 2019). 


\section{PRZESTRZENNE I FUNKCJONALNE ASPEKTY GOSPODARKI NOCNEJ NA KAZIMIERZU}

Badania nad rozkładem czasowo-przestrzennym gospodarki nocnej na obszarze Kazimierza objęły szczegółową inwentaryzację wszystkich obiektów funkcjonujących pomiędzy godziną 20:00 a 5:00 rano. Pierwszym krokiem było stworzenie bazy danych takich obiektów na podstawie zasobów internetowych. Następnie w marcu i kwietniu 2019 r. przeprowadzono kartowanie terenowe, w trakcie którego zweryfikowano tę bazę. $\mathrm{W}$ wyniku prac kameralnych oraz badań terenowych pozyskano następujący zakres informacji dotyczących badanych obiektów:

- nazwę obiektu,

- adres,

- godziny otwarcia i zamknięcia we wszystkie dni tygodnia,

- główną funkcję obiektu z uwzględnieniem dziewięciu kategorii szczegółowych (restauracje, bary, puby, dyskoteki i kluby, kawiarnie, sklepy, obiekty kultury, placówki zdrowia i urody oraz inne),

- informację na temat sprzedaży alkoholu.

W badaniach celowo pominięto kategorię obiekty noclegowe (łącznie 109), które zostały wliczone (jeśli prowadziły inną działalność poza udzielaniem noclegu) do poszczególnych kategorii.

Na potrzeby niniejszego opracowania zebrane informacje zaprezentowano w układzie wybranych dwóch dni tygodnia: wtorku (dzień roboczy) oraz soboty (dzień weekendu), a dokładnie nocy z wtorku na środę i nocy z soboty na niedzielę. W dalszej części opracowania (dla uproszczenia) autorzy posłużyli się nazwami dni rozpoczynających daną porę nocną, używając terminów noc wtorkowa i noc sobotnia. Dostępność czasową obiektów przedstawiono $w$ czterech momentach czasowych, o godz.: 20:00, 23:00, 2:00, 5:00, nawiązując do podziału NTE stosowanego w Sydney, w którym wyróżnia się: evening economy (20:00/21:00-23:00), night economy (23:00-2:00), late night economy (2:00-5:00).

Ogółem zidentyfikowano 408 obiektów usługowych, prowadzących działalność na Kazimierzu w godzinach 20:00-5:00. W strukturze rodzajowej gospodarki nocnej największy udział miały obiekty gastronomiczne - łącznie 278 placówek, które stanowiły 68,1\% ogółu. Wskazuje to na wyraźną "specjalizację produktową" tej części Krakowa. W tym miejscu należy podkreślić, że w ramach gospodarki nocnej funkcjonuje aż 80\% wszystkich obiektów świadczących usługi żywieniowe zlokalizowanych na Kazimierzu. Do grupy obiektów gastronomicznych czynnych w nocy zalicza się: 99 restauracji (24,3\% ogółu obiektów), 82 bary i fast foody (20,0\% ogółu), 64 puby (do kategorii tej zaliczono wszystkie lokale, w których dominująca działalnością jest sprzedaż alkoholu do konsumpcji na miejscu; łącznie 15,7\% ogółu) oraz 33 kawiarnie i cukiernie (8,1\% ogółu).

Pozostałe rodzaje obiektów zaliczonych do gospodarki nocnej na Kazimierzu to: sklepy - 42 (10,3\% ogółu obiektów); placówki oferujące usługi z zakresu zdrowia i urody - 29 (7,1\% ogółu); kluby muzyczne i dyskoteki - 14 (3,4\% ogółu); placówki kulturalne - tylko sześć obiektów (1,5\% ogółu). Do kategorii inne obiekty włączono 39 placówek (9,6\% ogółu). Są to m.in. podmioty związane z obsługą ruchu turystycznego, kantory, escape roomy, szkoły tańca, zakłady bukmacherskie.

Dostępność poszczególnych grup obiektów jest wyraźnie zróżnicowana, głównie z uwagi na przedział czasowy, w mniejszym zakresie ze względu na dzień tygodnia (zob. tab.1 i 2). Najwięcej podmiotów funkcjonuje w ramach evening economy. W dni robocze o godz. 20:00 dostępne jest 399 obiektów, natomiast $w$ weekendy - już tylko 365. Należy zauważyć, że dysproporcje te zaznaczają się przede wszystkim w przypadku placówek handlowych, placówek służących poprawie stanu zdrowia i urody oraz zaliczonych do kategorii inne. Jest to jak najbardziej prawidłowy rozkład aktywności podmiotów w rytmie tygodniowym i wskazuje na powiązanie tych miejsc z lokalnymi odbiorcami, a nie turystami. Na prawie niezmienionym poziomie utrzymuje się natomiast liczba lokali gastronomicznych (różnica tylko o 3 obiekty).

Pierwsze istotne zmiany w zakresie dostępności placówek obserwuje się o godz. 23:00. Jest to warunkowane w dużej mierze zmianami w komunikacji miejskiej (uruchomienie komunikacji nocnej z ograniczoną siatką połączeń). O tej porze nie funkcjonują już instytucje kulturalne, placówki z kategorii zdrowie i uroda oraz większość obiektów zaliczonych do grupy inne. Zmiany obserwuje się także w odniesieniu do sektora gastronomicznego, ponieważ we wtorki notuje się spadek liczby otwartych placówek o ponad połowę, natomiast $\mathrm{w}$ trakcie weekendu - $\mathrm{o} 1 / 3$. W przypadku sklepów spadek liczby czynnych lokali jest zbliżony i wynosi około $50 \%$. Odwrotne zjawisko - polegające na przyroście liczby otwartych placówek - uwidacznia się jedynie w przypadku klubów muzycznych i dyskotek, z których część zaczyna swoją działalność dopiero pomiędzy godz. 21:00 a 22:00. O godz. 2:00, tj. na początku late night economy, liczba aktywnych placówek zmniejsza się. W dni robocze o tej godzinie otwarte są jedynie 52 obiekty, z czego ponad połowę stanowią lokale gastronomiczne, natomiast $\mathrm{w}$ weekendy działa 99 podmiotów, z czego $3 / 4$ to obiekty gastronomiczne. O wiele większy spadek aktywności usługodawców pomiędzy godz. 20:00 a 2:00 notuje się $w$ dni robocze (blisko ośmiokrotny) niż w trakcie weekendów (ponad trzykrotny). W rytmie całonocnym (20:00-5:00) działa nie więcej niż 30 obiektów w weekendy oraz ok. 15 w dni robocze. Stanowi to odpowiednio 4,3\% ogółu podmiotów NTE we wtorki i 7,9\% w soboty. Całonocne 
usługi oferują placówki handlowe, dyskoteki i kluby muzyczne, a także obiekty gastronomiczne. W ramach tej ostatniej kategorii obserwuje się wyraźny wzrost liczby całonocnych placówek w porównaniu dni roboczych z weekendami, odpowiednio z 4 do 12.
Szczegółowa analiza dostępności czasowej obiektów gastronomicznych i gastronomiczno-rozrywkowych pozwoliła dostrzec kilka prawidłowości (tab. 3 i 4). Po pierwsze, po godz. 23:00 znacząco zmniejsza się liczba otwartych restauracji na Kazimierzu, co dotyczy

Tabela 1. Dostępność czasowa obiektów gospodarki nocnej na Kazimierzu we wtorki (stan na 2019 r.)

\begin{tabular}{|c|c|c|c|c|c|c|c|c|c|c|c|c|c|}
\hline \multirow{3}{*}{ Godzina } & \multirow{3}{*}{$\begin{array}{c}\text { Obiekty } \\
\text { ogółem }\end{array}$} & \multicolumn{12}{|c|}{ Typ obiektu } \\
\hline & & \multicolumn{2}{|c|}{$\begin{array}{c}\text { obiekty } \\
\text { gastronomiczne }\end{array}$} & \multicolumn{2}{|c|}{$\begin{array}{l}\text { dyskoteki } \\
\text { i kluby }\end{array}$} & \multicolumn{2}{|c|}{$\begin{array}{l}\text { placówki } \\
\text { handlowe }\end{array}$} & \multicolumn{2}{|c|}{$\begin{array}{c}\text { zdrowie } \\
\text { i uroda }\end{array}$} & \multicolumn{2}{|c|}{$\begin{array}{l}\text { placówki } \\
\text { kulturalne }\end{array}$} & \multicolumn{2}{|c|}{ inne } \\
\hline & & liczba & $\%$ & liczba & $\%$ & liczba & $\%$ & liczba & $\%$ & liczba & $\%$ & liczba & $\%$ \\
\hline $20: 00$ & 399 & 274 & 68,7 & 9 & 2,2 & 42 & 10,5 & 29 & 7,3 & 6 & 1,5 & 39 & 9,8 \\
\hline 23:00 & 182 & 150 & 82,5 & 11 & 6,0 & 18 & 9,8 & 0 & - & 0 & - & 3 & 1,7 \\
\hline $2: 00$ & 52 & 33 & 63,5 & 9 & 17,3 & 8 & 15,4 & 0 & - & 0 & - & 2 & 3,8 \\
\hline 5:00 & 17 & 4 & 23,5 & 5 & 29,4 & 6 & 35,3 & 0 & - & 0 & - & 2 & 11,8 \\
\hline
\end{tabular}

Źródło: opracowanie własne.

Tabela 2. Dostępność czasowa obiektów gospodarki nocnej na Kazimierzu w soboty (stan na 2019 r.)

\begin{tabular}{|c|c|c|c|c|c|c|c|c|c|c|c|c|c|}
\hline \multirow{3}{*}{ Godzina } & \multirow{3}{*}{$\begin{array}{c}\begin{array}{c}\text { Obiekty } \\
\text { ogółem }\end{array} \\
\text { liczba }\end{array}$} & \multicolumn{12}{|c|}{ Typ obiektu } \\
\hline & & \multicolumn{2}{|c|}{$\begin{array}{c}\text { obiekty } \\
\text { gastronomiczne }\end{array}$} & \multicolumn{2}{|c|}{$\begin{array}{l}\text { dyskoteki } \\
\text { i kluby }\end{array}$} & \multicolumn{2}{|c|}{$\begin{array}{l}\text { placówki } \\
\text { handlowe }\end{array}$} & \multicolumn{2}{|c|}{$\begin{array}{l}\text { zdrowie } \\
\text { i uroda }\end{array}$} & \multicolumn{2}{|c|}{$\begin{array}{l}\text { placówki } \\
\text { kulturalne }\end{array}$} & \multicolumn{2}{|c|}{ inne } \\
\hline & & liczba & $\%$ & liczba & $\%$ & liczba & $\%$ & liczba & $\%$ & liczba & $\%$ & liczba & $\%$ \\
\hline $20: 00$ & 365 & 277 & 75,9 & 10 & 2,7 & 37 & 10,1 & 10 & 2,7 & 6 & 1,6 & 25 & 6,8 \\
\hline $23: 00$ & 234 & 196 & 83,8 & 14 & 6,0 & 20 & 8,5 & 0 & - & 0 & - & 4 & 1,7 \\
\hline $2: 00$ & 99 & 75 & 75,8 & 13 & 13,1 & 9 & 9,1 & 0 & - & 0 & - & 2 & 2,0 \\
\hline $5: 00$ & 29 & 12 & 41,4 & 9 & 31,0 & 6 & 20,7 & 0 & - & 0 & - & 2 & 6,9 \\
\hline
\end{tabular}

Źródło: opracowanie własne.

Tabela 3. Dostępność czasowa obiektów gastronomicznych zaliczanych do gospodarki nocnej na Kazimierzu we wtorki (stan na 2019 r.)

\begin{tabular}{|c|c|c|c|c|c|c|c|c|c|}
\hline \multirow{2}{*}{ Godzina } & \multirow{2}{*}{$\begin{array}{c}\text { Obiekty gastronomiczne } \\
\text { ogółem }\end{array}$} & \multicolumn{9}{|c|}{ Typ obiektu } \\
\cline { 2 - 12 } & liczba & restauracje & \multicolumn{2}{|c|}{ bary } & \multicolumn{3}{|c|}{ puby } & \multicolumn{2}{c|}{ kawiarnie } \\
\hline & 274 & liczba & $\%$ & liczba & $\%$ & liczba & $\%$ & liczba & $\%$ \\
\hline $20: 00$ & 150 & 44 & 29,3 & 36 & 24,0 & 62 & 41,3 & 8 & 5,3 \\
\hline $2: 00$ & 33 & 1 & 3,0 & 10 & 30,3 & 21 & 63,6 & 1 & 3,0 \\
\hline $5: 00$ & 4 & 0 & - & 0 & - & 4 & 100,0 & 0 & - \\
\hline
\end{tabular}

Źródło: opracowanie własne.

Tabela 4. Dostępność czasowa obiektów gastronomicznych zaliczanych do gospodarki nocnej na Kazimierzu w soboty (stan na 2019 r.)

\begin{tabular}{|c|c|c|c|c|c|c|c|c|c|}
\hline \multirow{3}{*}{ Godzina } & \multirow{3}{*}{$\begin{array}{c}\begin{array}{c}\text { Obiekty gastronomiczne } \\
\text { ogółem }\end{array} \\
\text { liczba }\end{array}$} & \multicolumn{8}{|c|}{ Typ obiektu } \\
\hline & & \multicolumn{2}{|c|}{ restauracje } & \multicolumn{2}{|c|}{ bary } & \multicolumn{2}{|c|}{ puby } & \multicolumn{2}{|c|}{ kawiarnie } \\
\hline & & liczba & $\%$ & liczba & $\%$ & liczba & $\%$ & liczba & $\%$ \\
\hline $20: 00$ & 277 & 99 & 35,7 & 82 & 29,6 & 64 & 23,1 & 32 & 11,6 \\
\hline $23: 00$ & 196 & 68 & 34,7 & 54 & 27,6 & 63 & 32,1 & 11 & 5,6 \\
\hline 2:00 & 75 & 8 & 10,7 & 19 & 25,3 & 47 & 62,7 & 1 & 1,3 \\
\hline 5:00 & 12 & 1 & 8,3 & 0 & - & 11 & 91,7 & 0 & - \\
\hline
\end{tabular}

Źródło: opracowanie własne. 
zarówno dni roboczych, jak i weekendów. O godz. 2:00 większość lokali jest już niedostępna, co jest typowe także dla innych miast i wiąże się z ograniczeniem czasu pracy kuchni. Po drugie, w ramach klasycznej night economy rośnie znaczenie barów, które oferują węższy zakres produktów. Znaczny odsetek w tej grupie stanowią bary typu fast food, a tak zwana uliczna gastronomia (street food) ściśle wiąże się z wspomnianą już wcześniej prostą rozrywką (middlebrow partying), opartą na konsumpcji alkoholu. Po trzecie, wraz $\mathrm{z}$ wkraczaniem $\mathrm{w}$ porę nocną $\mathrm{w}$ strukturze gospodarki nocnej rośnie udział placówek, dla których podstawą działalności jest sprzedaż alkoholu. Dotyczy to zarówno sklepów monopolowych, jak i pubów (rys. 2). Już o godzinie 20:00 odsetek lokali, w których sprzedaje się alkohol jest wysoki, we wtorek wynosi on $54,4 \%$, natomiast w sobotę - ponad $60 \%$. W przypadku godzin 23:00 i 2:00, kiedy wśród otwartych lokali zaczynają przeważać puby, odsetek ten oscyluje już wokół $75 \%$. Wśród obiektów dostępnych o godzinie 5:00 zarówno $\mathrm{w}$ dni robocze, jak i w trakcie weekendu zaznacza się dominacja placówek związanych z dystrybucją alkoholu (odpowiednio $88,2 \%$ we wtorek i 93,1\% w sobotę). Jedynymi lokalami, w których nie sprzedaje się alkoholu o tej porze, są lombard przy ulicy Dietla 7 oraz salon gier przy Placu Nowym 3.

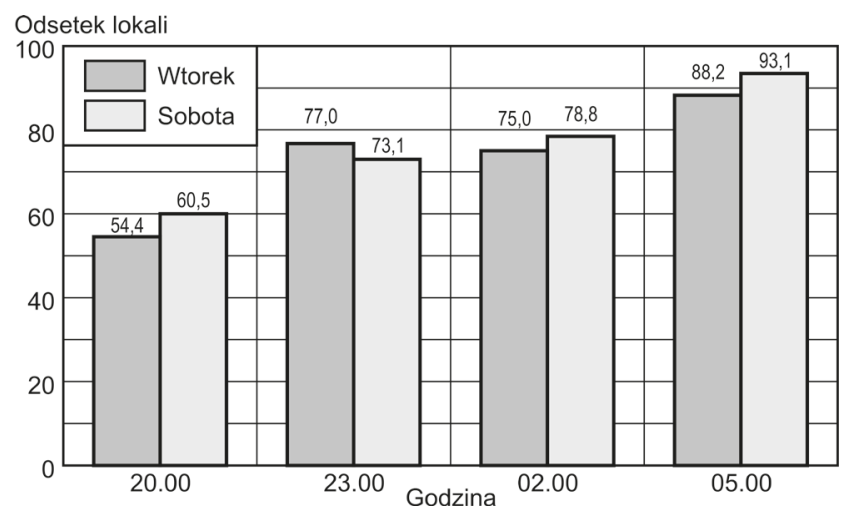

Rysunek 2. Odsetek lokali sprzedających alkohol w godzinach wieczornych i nocnych na Kazimierzu Źródło: Mróz (2019)

Oferta gastronomiczna w porze nocnej na Kazimierzu jest zróżnicowana, od typowego street foodu do fine diningu. Jak zauważa Murzyn (2006), już od lat 90. XX w. w tej części Krakowa panuje prawdziwy gastronomiczny boom. Do tego czasu większość placówek gastronomicznych zlokalizowana była wzdłuż głównych ulic - Krakowskiej, Starowiślnej oraz Dietla (por. Więcław, 1997). W późniejszym okresie gastronomia wkroczyła w obręb tzw. kwartału żydowskiego (Murzyn, 2006). Wyraźnie zaznaczają się dwie strefy: na ulicy Szerokiej, gdzie zlokalizowane są sztandarowe lokale gastronomiczne Kazimierza, wyspecjalizowane w kuchni żydowskiej oraz wokół Placu Nowego, gdzie oferta jest bardziej zróżnicowana (Mika, 2011). Ich uzupełnieniem są lokale wzdłuż ulic Mostowej, Bożego Ciała, Józefa i Miodowej. Wiele restauracji funkcjonuje w ramach hoteli, przy czym swoją ofertę kierują także do gości z zewnątrz. W ostatnich latach na Kazimierzu powstały pierwsze ogródki food truckowe, z najbardziej znanym przy ulicy św. Wawrzyńca. Niezwykle popularne są także kawiarnie i cukiernie - w sobotę, jak i we wtorek po godzinie 20:00 otwartych jest ponad 30 lokali tego typu. Wyróżniają się one lokalnym charakterem i często nawiązują do przeszłości dzielnicy, np. Mleczarnia. Co istotne, na Kazimierzu nie działa ani jedna kawiarnia sieciowa typu Starbucks czy Costa Caffee. Takie placówki w Krakowie zlokalizowane są przede wszystkim w obrębie Starego Miasta i jego okolicach oraz $\mathrm{w}$ galeriach handlowych. Lokalnym charakterem odznaczają się również puby, z których wiele uznaje się za markowe (np. Alchemia). Ich oferta często jest poszerzana o koncerty muzyczne i inne wydarzenia. Na Kazimierzu działają także puby tematyczne, np. Domówka Cafe, popularny wśród miłośników gier planszowych. Niestety w przestrzeń dzielnicy wkroczyły również sieciowe bary alkoholowe, jak Pijalnia Wódki i Piwa, które stały się wręcz symbolem taniej rozrywki alkoholowej. Działają one na zasadzie franczyz, a ich strategia marketingowa opiera się na ekonomii skali. Oferta ta jest atrakcyjna głównie dla studentów i młodych turystów z zagranicy, dla których magnesem jest relatywnie niska cena, np. około 1 euro za napój alkoholowy.

Analizując przedstawione na rysunkach 3-10 przestrzenne rozmieszczenie obiektów, dostępnych na Kazimierzu w godzinach wieczornych i nocnych można dostrzec wyraźne tendencje do skupiania się ich w konkretnych strefach. W studiach nad gospodarką nocną miejsca o dużej koncentracji obiektów oraz popularne przestrzenie spotkań uczestników życia nocnego (place itp.) określa się mianem nocnych hot spotów. Na Kazimierzu można wyróżnić co najmniej cztery takie strefy, trzy mają charakter placów, czwarta - ciągu ulicznego. Należy zauważyć, że ze względu na niewielką powierzchnię dzielnicy miejsca te praktycznie sąsiadują ze sobą.

Pierwszą ze stref jest Plac Nowy. Miejsce to funkcjonuje aktywnie zarówno w ciągu dnia, jak i w nocy. Za dnia plac ten pełni funkcje handlowe i gastronomiczne (od południa), wraz z upływem godzin zmienia się jego charakter, aby w porze wieczornej przeobrazić się w zatłoczone miejsce spotkań ludzi. Wokół placu działa kilkanaście pubów i restauracji cieszących się dużą renoma a w jego centrum znajduje się słynny Okrąglak - budynek dawnej rzeźni, w tej chwili funkcjonuje w nim kilkanaście barów z popularnymi zapiekankami, które urosły do miana symbolu 
gastronomicznego Kazimierza. Regulamin handlowy Placu Nowego dopuszcza aktywność gospodarczą do godziny 2:00. W ostatnich latach na obszarze tym zaszły znaczące zmiany zarówno w zakresie komunikacji, m.in. znacznie ograniczono ruch pojazdów (miało to swój początek w 2016 r. po happeningu aktywistów, w trakcie którego wyłączono z ruchu dwie pierzeje placu), jak i organizacji handlu (Grochowicz, 2019). Nie wszystkie z przeprowadzonych modernizacji przyniosły zamierzony efekt. Niezależnie od tego, miejsce to cieszy się największą popularnością wśród uczestników życia nocnego na całym Kazimierzu. Na Placu Nowym występuje największe skupisko lokali otwartych do godziny 5:00 zarówno w dni robocze, jak i w trakcie weekendu.

Kolejną strefą jest ulica Szeroka, która swoim układem przestrzennym przypomina bardziej plac niż ciąg komunikacyjny. Jak już wspomniano, znajduje się tutaj wiele restauracji wyspecjalizowanych w kuchni żydowskiej, takich jak Ariel i Szara. Obok nich działa kilka pubów. Specyfiką tej części Kazimierza jest wyraźne ukierunkowanie na obsługę turystów zagranicznych. W lipcu na ulicy Szerokiej odbywa się finałowy koncert w ramach międzynarodowego Festiwalu Kultury Żydowskiej.

Dwie pozostałe strefy obejmują ulicę Mostową - wschodnią pierzeję placu Wolnica, ulicę Bożego Ciała i zachodni fragment ulicy Miodowej (pierwsza strefa) oraz obszar na skrzyżowaniu ulic św. Wawrzyńca i Wąskiej (druga strefa). Pierwsza lokalizacja ma charakter strefy tranzytowej z Kazimierza na Podgórze, przy której zlokalizowanych jest kilkanaście obiektów gastronomicznych, w tym kilka dostępnych do późnych godzin nocnych. Biegnie ona równolegle do głównej arterii Kazimierza - ulicy Krakowskiej. Druga to najpopularniejszy ogródek z food truckami na Kazimierzu - Judah Square Food Truck Park przy ulicy św. Wawrzyńca. W jego bezpośrednim sąsiedztwie znajduje się Stara Zajezdnia - jeden z największych, pod względem liczby miejsc dla gości, obiektów gastronomicznych czynnych nocą na Kazimierzu.

W przestrzeni Kazimierza możemy wyróżnić również strefy bez „życia nocnego" - jest to przede wszystkim zachodnia część dzielnicy (na zachód od ulicy Krakowskiej) oraz wschodnie obrzeża Kazimierza (obszar pomiędzy ulicą Starowiślną a nasypem kolejowym). Stosunkowo słabo zagospodarowane na potrzeby gospodarki nocnej są także bulwary wiślane. Atrakcyjność tego miejsca dla rozrywki nocnej wiąże się z sąsiedztwem Kładki Ojca Bernatka (zrealizowanej w 2010 r.), z przycumowanymi barkami rzecznymi oraz sąsiedztwem pubów i restauracji na drugim brzegu Wisły, po stronie Podgórza.

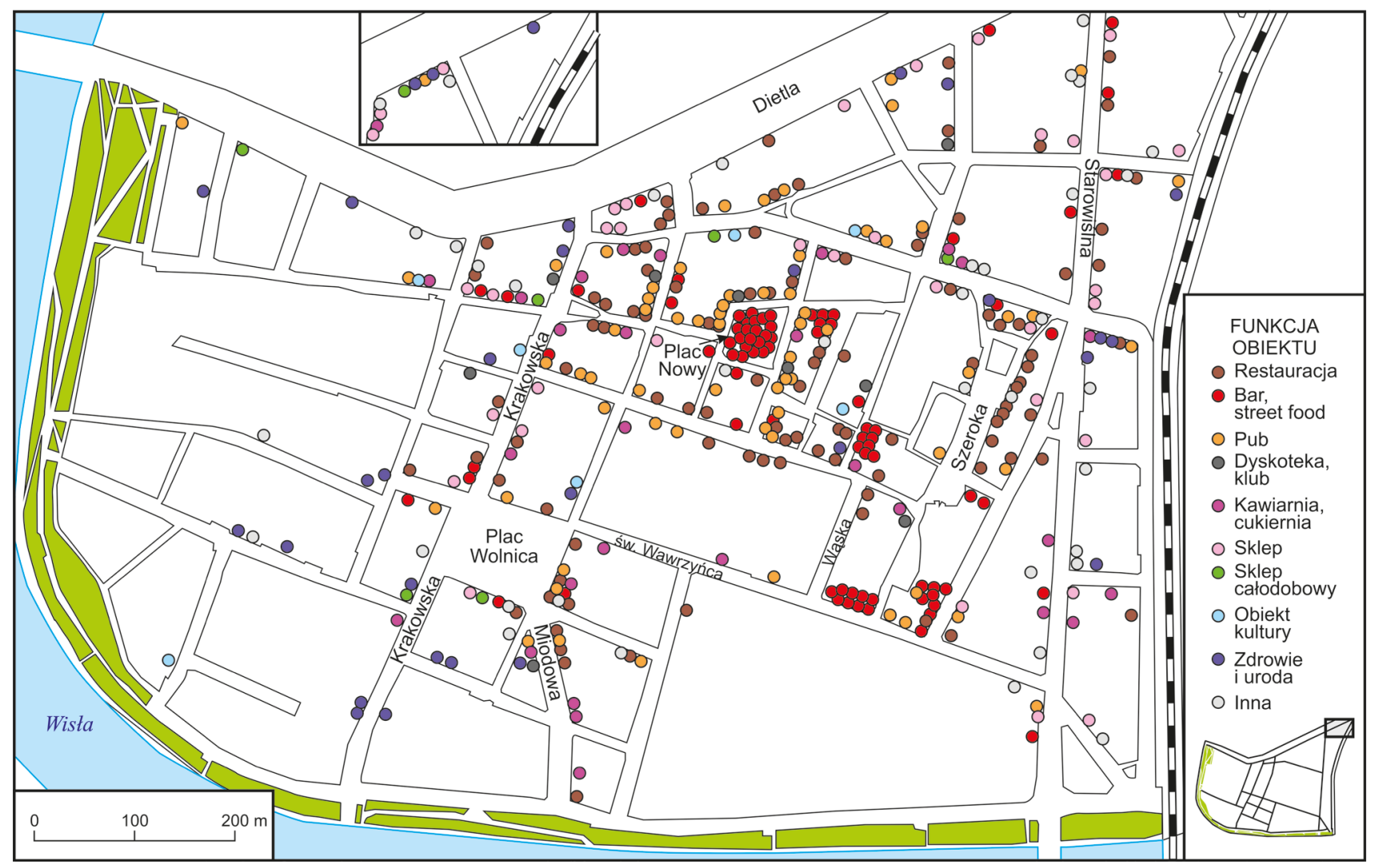

Rysunek 3. Przestrzenne rozmieszczenie obiektów czynnych we wtorek o godzinie 20:00 Źródło: Mróz (2019) 


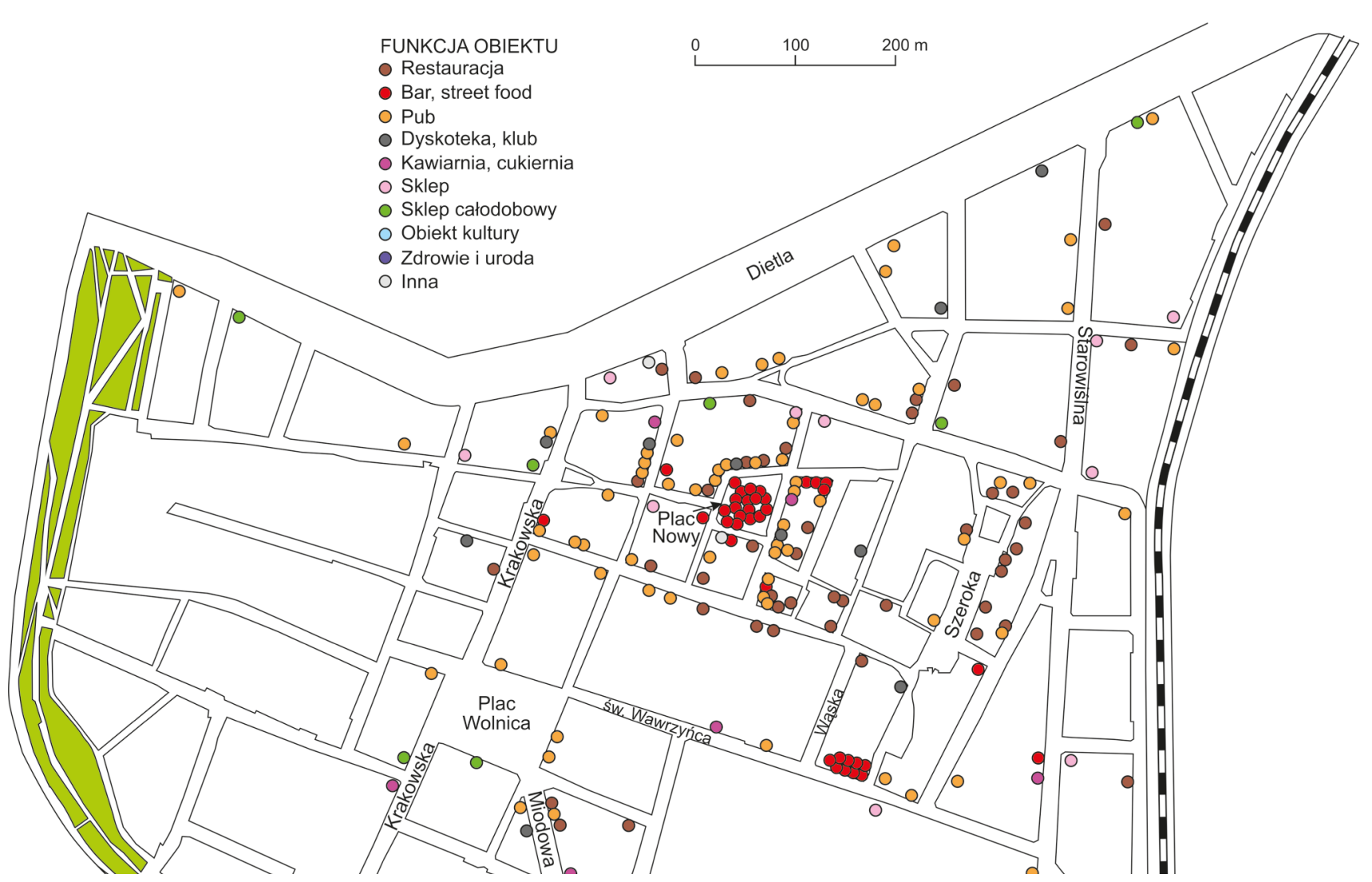

Rysunek 4. Przestrzenne rozmieszczenie obiektów czynnych we wtorek o godzinie 23:00 Źródło: Mróz (2019)

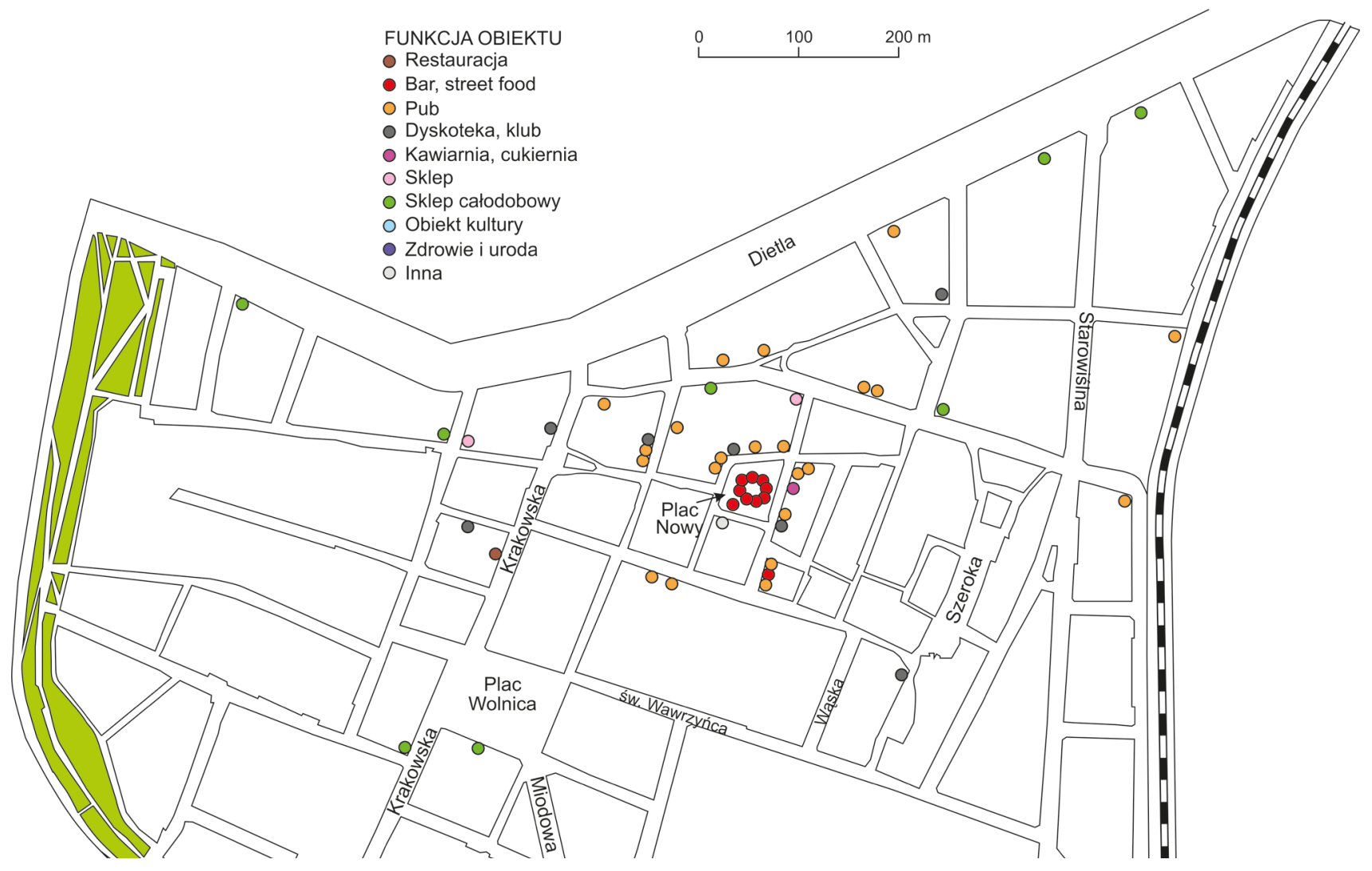

Rysunek 5. Przestrzenne rozmieszczenie obiektów czynnych w środę o godzinie 2:00 Źródło: Mróz (2019) 


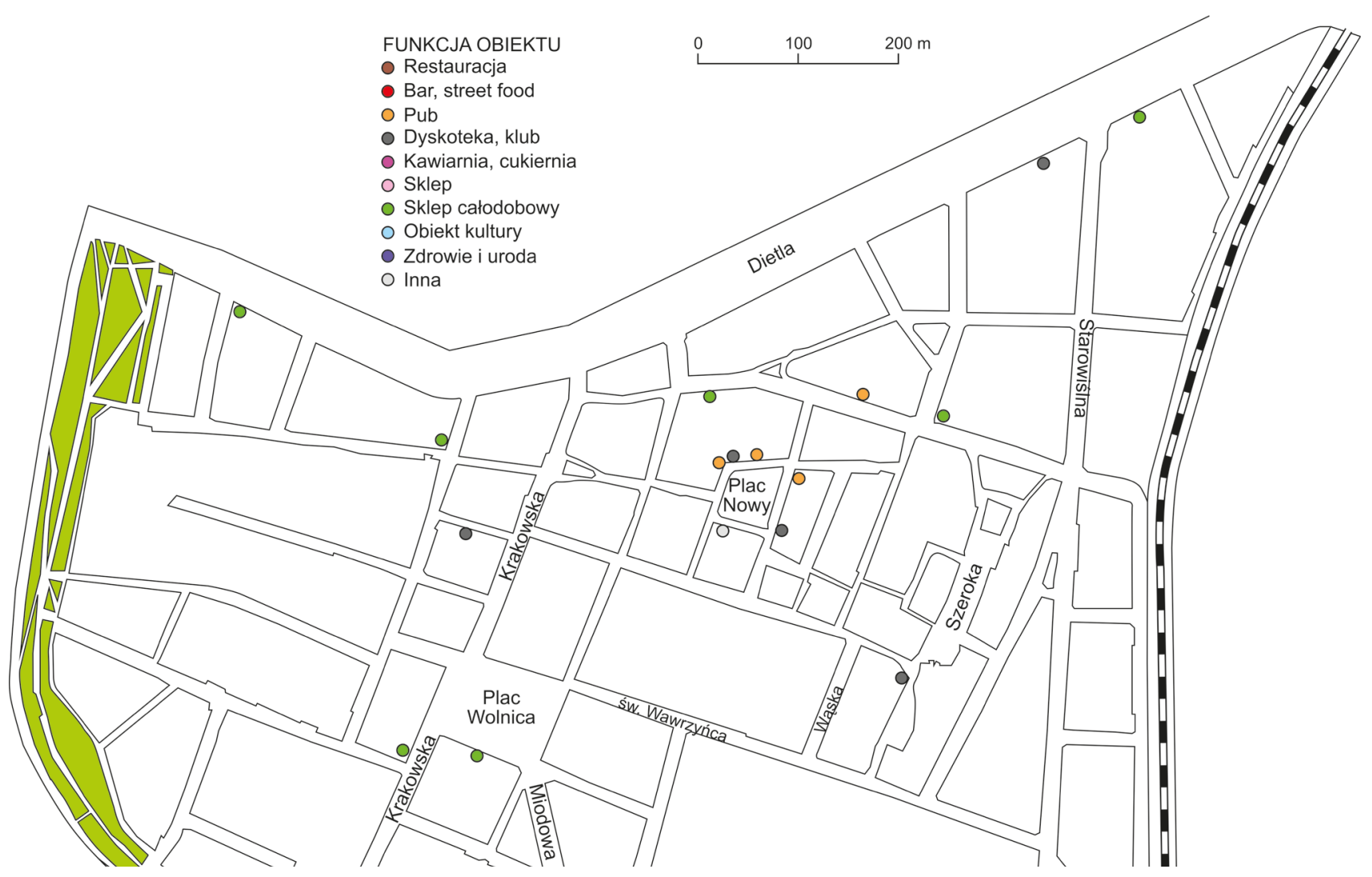

Rysunek 6. Przestrzenne rozmieszczenie obiektów czynnych w środę o godzinie 5:00 Źródło: Mróz (2019)

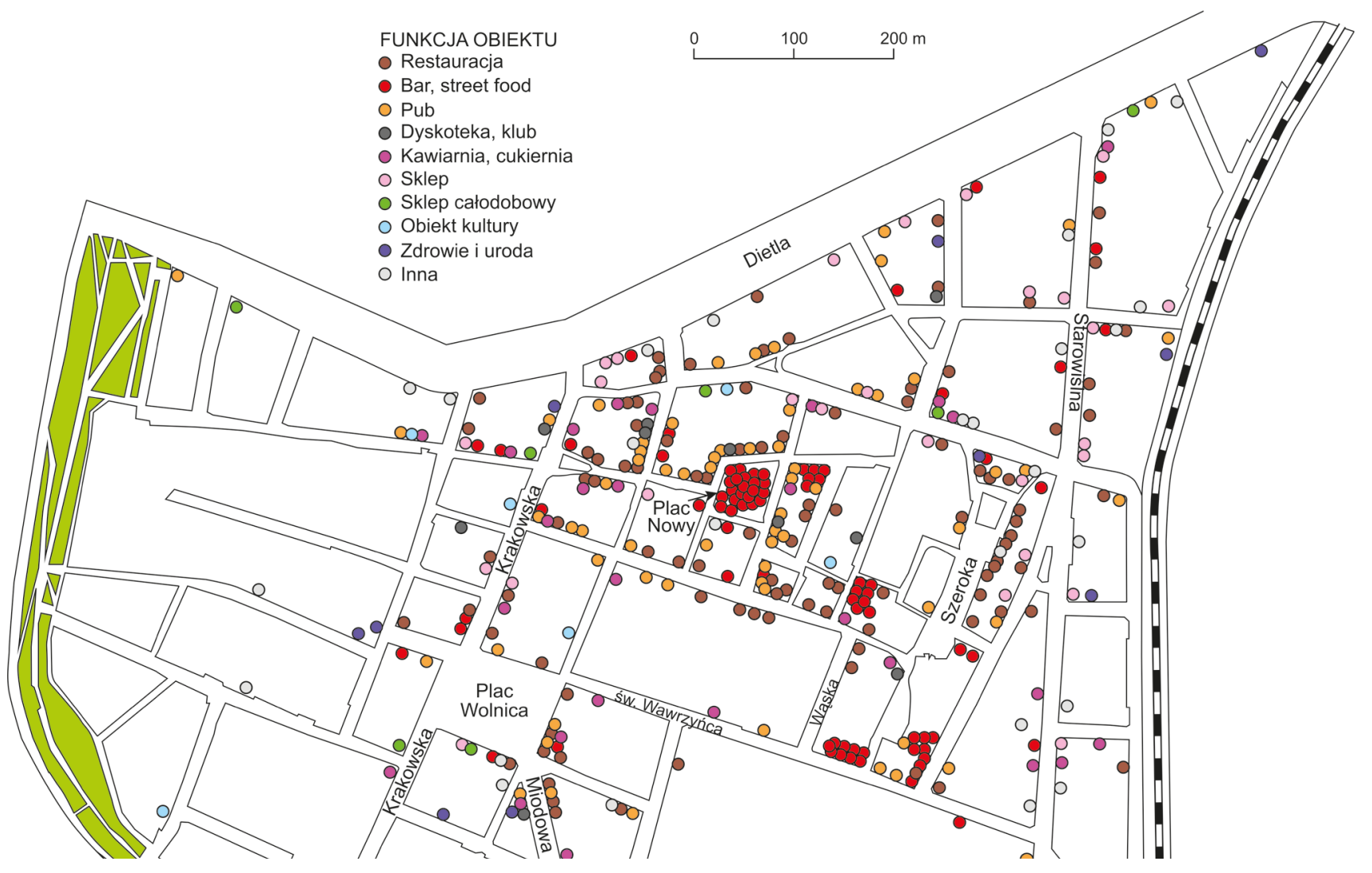

Rysunek 7. Przestrzenne rozmieszczenie obiektów czynnych w sobotę o godzinie 20:00 Źródło: Mróz (2019) 


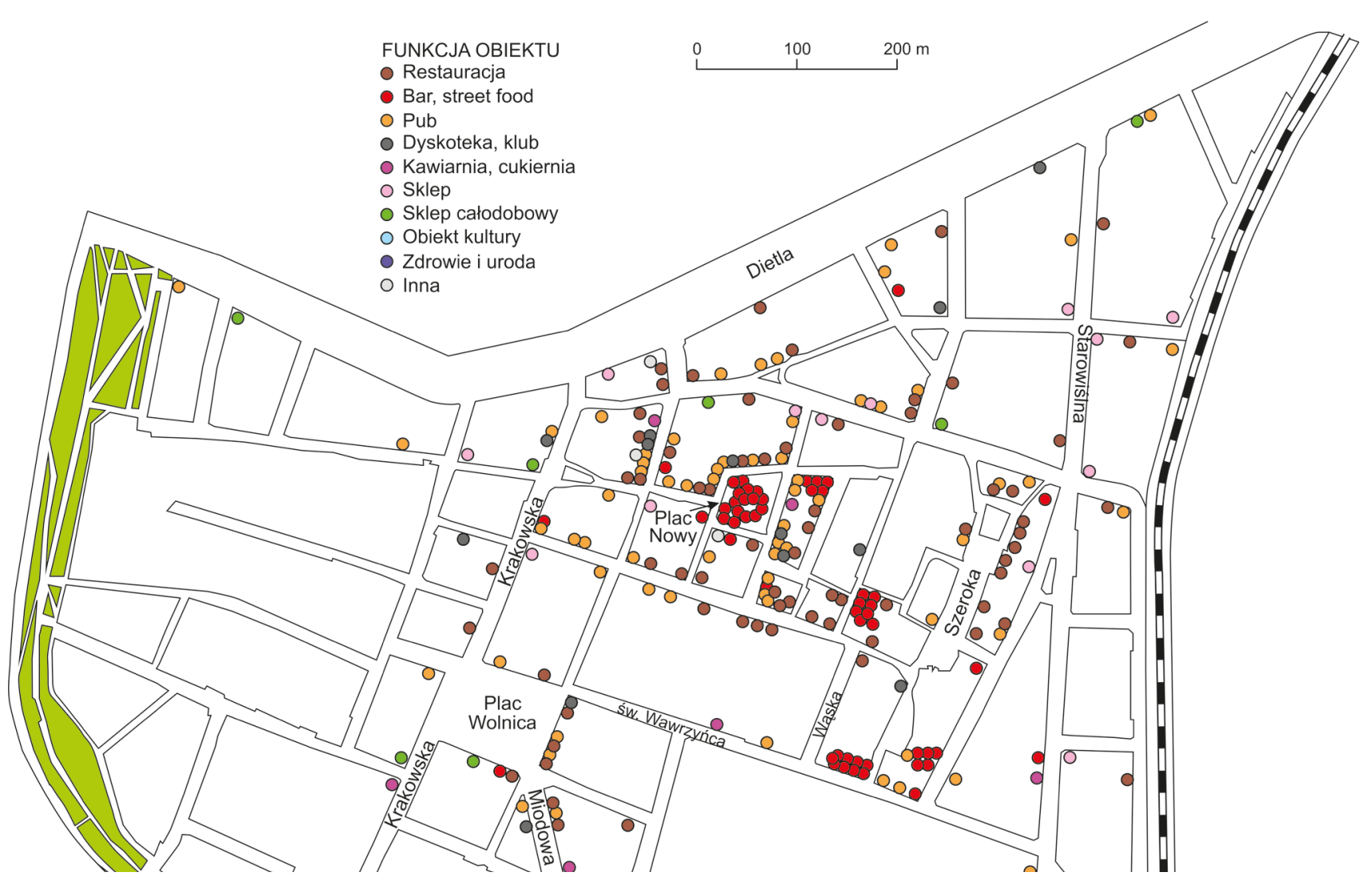

Rysunek 8. Przestrzenne rozmieszczenie obiektów czynnych w sobotę o godzinie 23:00 Źródło: Mróz (2019)

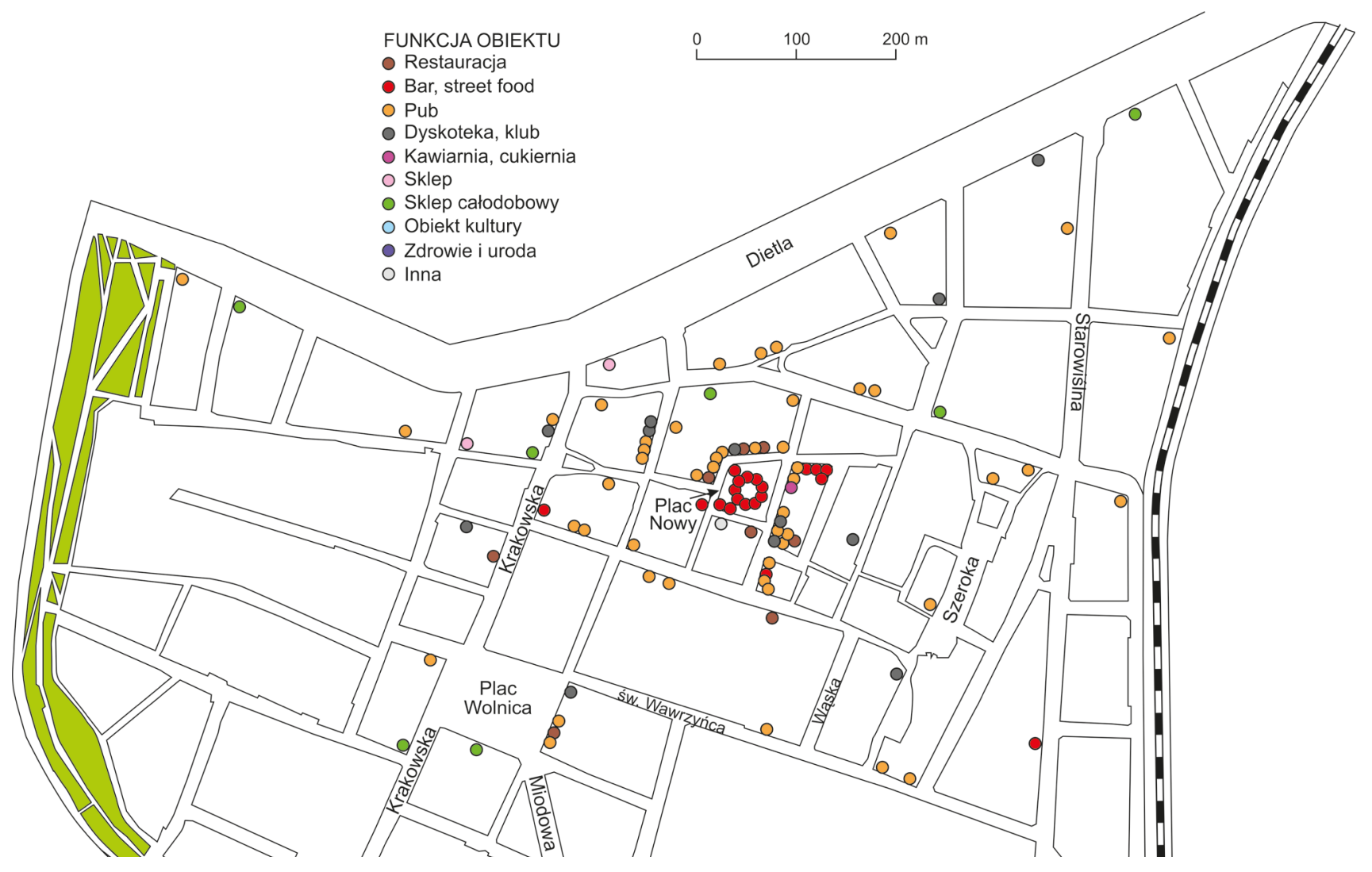

Rysunek 9. Przestrzenne rozmieszczenie obiektów czynnych w niedzielę o godzinie 2:00 Źródło: Mróz (2019) 


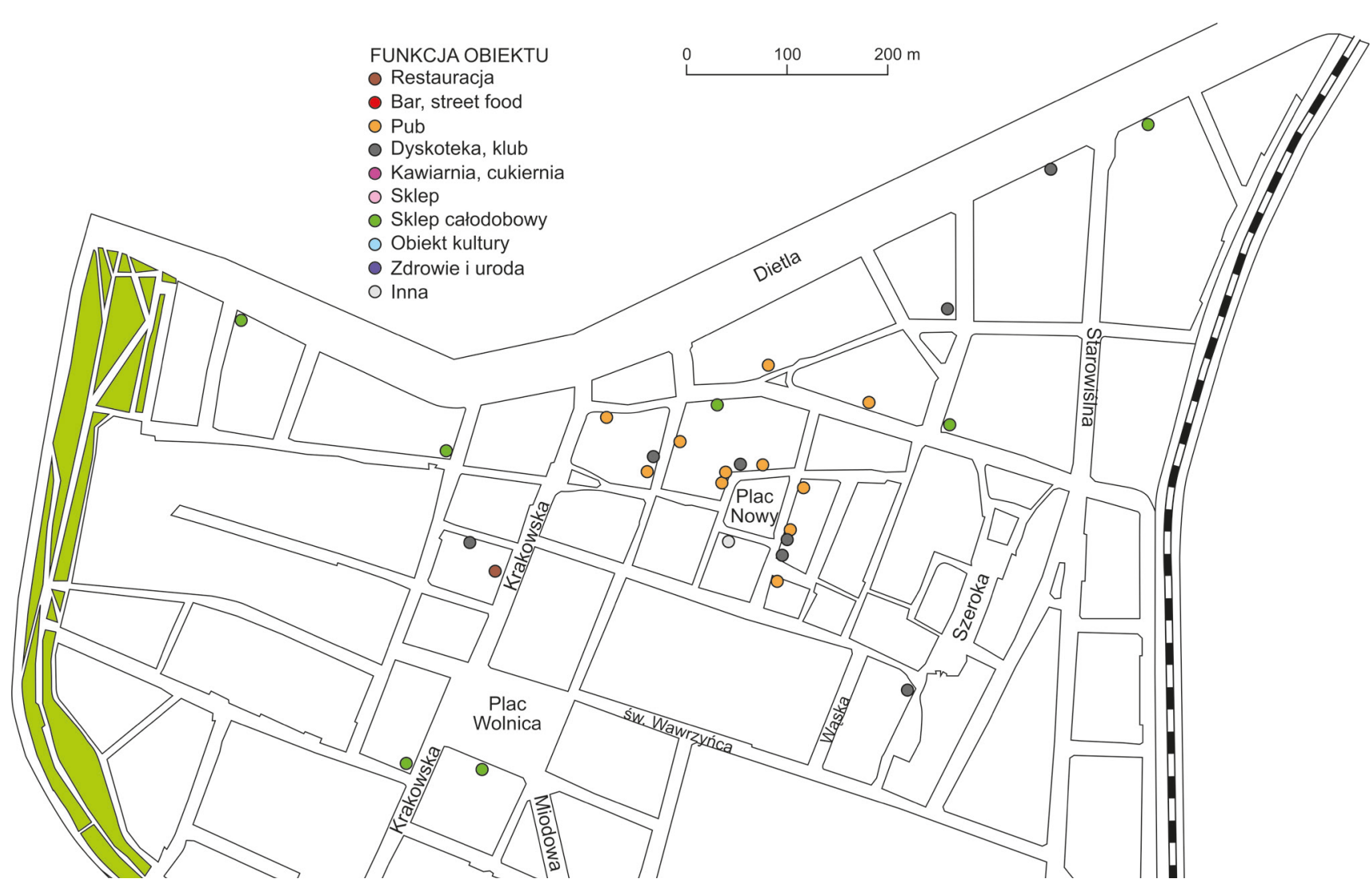

Rysunek 10. Przestrzenne rozmieszczenie obiektów czynnych w niedzielę o godzinie 5:00 Źródło: Mróz (2019)

\section{SPOŁECZNE KONSEKWENCJE ROZWOJU GOSPODARKI NOCNEJ NA KAZIMIERZU}

Kazimierz w ciaggu ostatnich 30 lat przeszedł wiele intensywnych zmian społecznych i gospodarczych. Przez cały okres powojenny obszar ten był kojarzony z zaniedbaną przestrzenia, opuszczonymi budynkami, przestępczością i niskim standardem życia, a dziedzictwo kultury żydowskiej traktowane było w kategoriach dziedzictwa niechcianego (por. Murzyn-Kupisz, 2008). Dopiero wraz z uruchomieniem procesów transformacji gospodarczej w latach 90 . XX w. pojawily się warunki do odrodzenia Kazimierza. Zapoczątkowano wówczas dyskusję nad rewitalizacją dzielnicy (mimo, że ta część miasta została wpisana wraz ze Starym Miastem na Listę Światowego Dziedzictwa UNESCO już w 1978 r.). Ponadto dostrzeżono wartość znajdującego się tam dziedzictwa kultury żydowskiej, co dało początek Festiwalowi Kultury Żydowskiej (od 1988 r.) (Pawlusiński, Kubal, 2011). Z uwagi na duże niedoinwestowanie i zaniedbaną przestrzeń obszar Kazimierza, w przeciwieństwie do Starego Miasta, dość długo nie cieszył się zainteresowaniem ze strony turystów ani nie przyciagał inwestorów z sektora turystycznego. Dopiero pod koniec lat 90. XX w. krakowscy przedsiębiorcy zwrócili uwagę na możliwość uruchomienia na Kazimierzu pubów, które stawały się coraz bardziej popularne wśród studentów, turystów i młodych mieszkańców miasta. Jako pierwsze powstały, działające do dzisiaj w sąsiedztwie Placu Nowego, kluby Singer oraz Alchemia, stając się wyznacznikami „kultury nocnej” tej części Krakowa. Jednocześnie przy ulicy Szerokiej powstały restauracje z kuchnią żydowską. Krakowski Kazimierz stał się atrakcyjnym miejscem spędzania wolnego czasu, oferując nowy produkt miejski, bazujący z jednej strony na życiu nocnym, a z drugiej - nawiązujący do dziedzictwa żydowskiego (Pawlusiński, Kubal-Czerwińska, 2018). Podobne procesy w odniesieniu do kwartałów żydowskich obserwowano w Pradze czy Budapeszcie.

Z badań przeprowadzonych przez autorów wynika, że w 2003 r. na Kazimierzu funkcjonowało już 118 obiektów gastronomicznych, a w 2016 r. - blisko 300. Początkowo życie nocne nie przysparzało mieszkańcom większych problemów. Za bardziej dotkliwy uznawano wzrost kosztów życia, związany z reorientacją lokalnej gospodarki na sektor czasu wolnego i obsługę turystów. Proces ten w literaturze szeroko omówiła Kowalczyk-Anioł (2019), pisząc o zjawisku gentryfikacji turystycznej. W efekcie tych zmian Kazimierz zaczął tracić mieszkańców. W 2003 r. dzielnicę zamieszkiwało ok. 13 tys. osób, dziesięć lat później liczba ta skurczyła się do kilku tysięcy. Znacząco zmieniła się także 
struktura społeczna mieszkańców. W miejsce dotychczasowej ludności napływały nowe grupy społeczne i zawodowe. Kazimierz stał się popularny zwłaszcza wśród artystów, przedstawicieli świata nauki oraz studentów. Stopniowo zmieniała się tkanka miejska - odnawiano budynki i upiększano przestrzeń publiczną (Murzyn, 2006). W konsekwencji Kazimierz zaczął cieszyć się popularnością wśród jeszcze zamożniejszych grup mieszkańców, wypierając m.in. artystów (por. Działek, Murzyn-Kupisz, 2015), ale także wśród zagranicznych turystów. Wraz z rozwojem city break liczba turystów nastawionych na prostą rozrywkę zwielokrotniła się. Młodzi ludzie zarówno z Polski, jak i z zagranicy zaczęli postrzegać Kazimierz jako ważną strefę rozrywki nocnej w Krakowie (obok Starego Miasta). Po 2010 r. wraz z upowszechnieniem najmu krótkoterminowego mieszkań turystom, m.in. za pośrednictwem internetowej platformy Airbnb, życie nocne na Kazimierzu objęło nie tylko partery budynków, gdzie zlokalizowane są puby i inne lokale, ale weszło także na wyższe kondygnacje kamienic. W mediach coraz powszechniejsze stawały się relacje mieszkańców z ekscesów nocnych ich tymczasowych sąsiadów.

Napięcia społeczne na Kazimierzu generowało nie tylko życie nocne, ale także ogólne przesycenie turystyczne oraz nowe koncepcje organizacji przestrzeni w dzielnicy, w tym zmiany dotyczące parkowania i poruszania się samochodem w jej obrębie. Mieszkańcy coraz częściej zaczęli artykułować swój sprzeciw wobec, ich zdaniem, niekontrolowanego rozwoju szeroko rozumianego sektora czasu wolnego. Potwierdzają to wypowiedzi mieszkańców w trakcie wywiadów: „Turyści na początku byli dla nas zbawieniem, mówiło się o Kazimierzu, odnawiano kamienice... Teraz są przekleństwem.”; „Kazimierz przekształca się w jeden wielki hostel/bar z tanim alkoholem,"; „Czujemy się intruzami, którzy tylko i wyłącznie mają płacić tutaj podatki.”; „W weekend większość mieszkańców Kazimierza wyjeżdża poza miasto, tutaj nie da się żyć."; „Stare Miasto jest już stracone, trochę lepiej jest na Kazimierzu, ale to też tutaj przychodzi i lada dzień tutaj nie będzie wielu mieszkańców".

Wśród najważniejszych uciążliwości wskazywano hałas generowany zarówno przez samych uczestników życia nocnego (m.in. głośne rozmowy przed lokalami, hałaśliwe przemarsze grup ludzi; organizowanie prywatnych przyjęć dla kilkudziesięciu osób w mieszkaniach wynajmowanych w ramach Airbnb), jak i związany z funkcjonowaniem pubów (muzyka w lokalu, głośna praca urządzeń klimatyzacyjnych umieszczonych na zewnątrz kamienic). Innymi zgłaszanymi uciążliwościami były: spożywanie alkoholu w niedozwolonych miejscach, załatwianie potrzeb fizjologicznych na klatach schodowych czy dzwonienie do drzwi sąsiednich lokali w celu identyfikacji miejsca swojej kwatery. Czasami agresywni uczestnicy życia nocnego dokonywali aktów wandalizmu, często wszczynali także bójki - z mieszkańcami, innymi turystami, jak i między sobą.

W ostatnich latach dyskusja na temat negatywnych konsekwencji życia nocnego na Kazimierzu oraz na Starym Mieście w Krakowie była nie tylko szeroko opisywana $\mathrm{w}$ prasie, ale zdominowała wiele spotkań z radnymi, przedstawicielami władz miasta oraz aktywistami społecznymi. W grudniu 2018 r. aktywiści miejscy zainicjowali w Krakowie debatę, pierwszą z cyklu, na temat turystyfikacji miasta. Impulsem do tego była decyzja o likwidacji staromiejskiego kina Ars mieszczącego się przy ul. św. Jana i przeznaczeniu tego budynku na kolejny hotel. W spotkaniach tych uczestniczyli przedstawiciele Urzędu Miasta Krakowa.

W pierwszych dniach sierpnia 2019 r., jako wyraz protestu przeciwko nadmiernej turystyfikacji i życiu nocnemu, w przestrzeni Kazimierza pojawiły się klepsydry, obwieszczające, że w ciągu ostatnich dwóch dekad Kazimierz Cichy zmarł (fot. 1). Akcja ta poprzedziła podjętą później przez radnych dzielnicowych kampanię informacyjną, skierowaną do turystów. Jej elementem były plakaty, nawołujące do uszanowania ciszy nocnej, które zostały umieszczone w różnych miejscach na Kazimierzu oraz na Starym Mieście (fot. 2 i 3).

Mieszkańcy coraz głośniej swój sprzeciw zgłaszali Radzie Miasta Krakowa, a szerokim echem odbiło się m.in. nieuchwalenie w 2018 r. ograniczenia sprzedaży alkoholu w sklepach w porze nocnej. Mimo, że w końcu 2018 r. Rada Miasta Krakowa przyjęła uchwałę na temat zakazu handlu alkoholem w obrębie I dzielnicy (Stare Miasto i Kazimierz) w godz. 22:00-6:00, to jednak również ten akt nie rozwiązał problemu, gdyż został zaskarżony przez jednego z przedsiębiorców. Ograniczenie sprzedaży alkoholu w sklepach nocnych było jednym z ważniejszych postulatów mieszkańców. Wydaje się on w pełni słuszny, ponieważ jedną z przyczyn nadmiernego spożywania przez młodzież

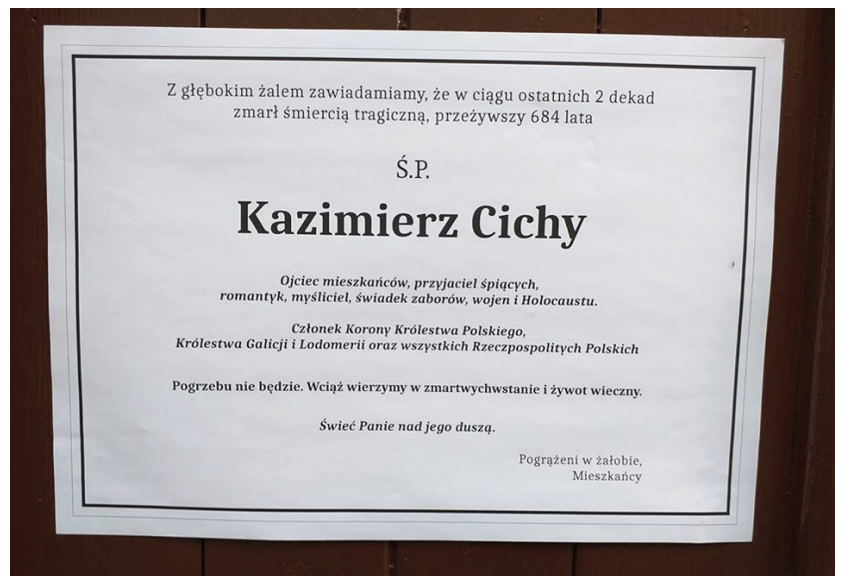

Fotografia 1. Plakaty zawieszone na Kazimierzu w 2019 r. przez mieszkańców Źródło: R. Pawlusiński 


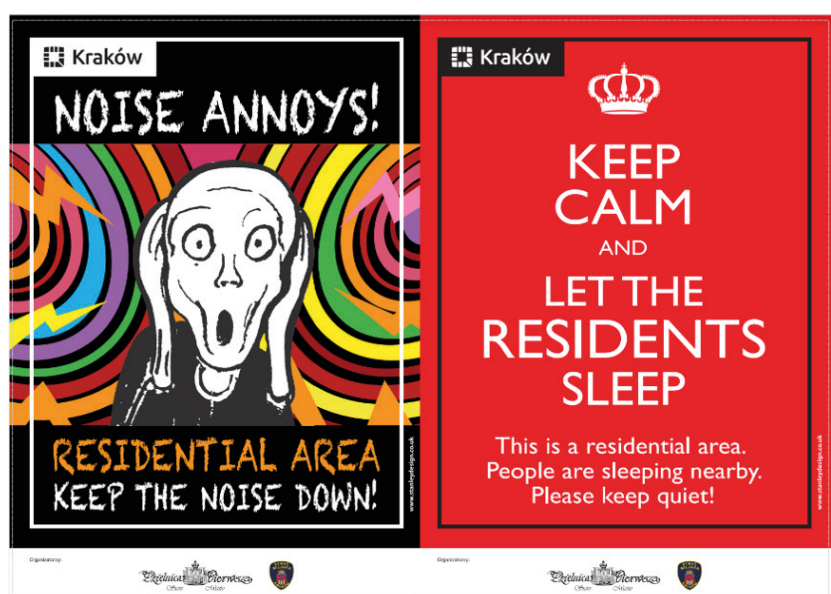

Fotografia 2. Plakaty informacyjne zawieszone w historycznej części Krakowa w 2019 r. Źródło: R. Pawlusiński

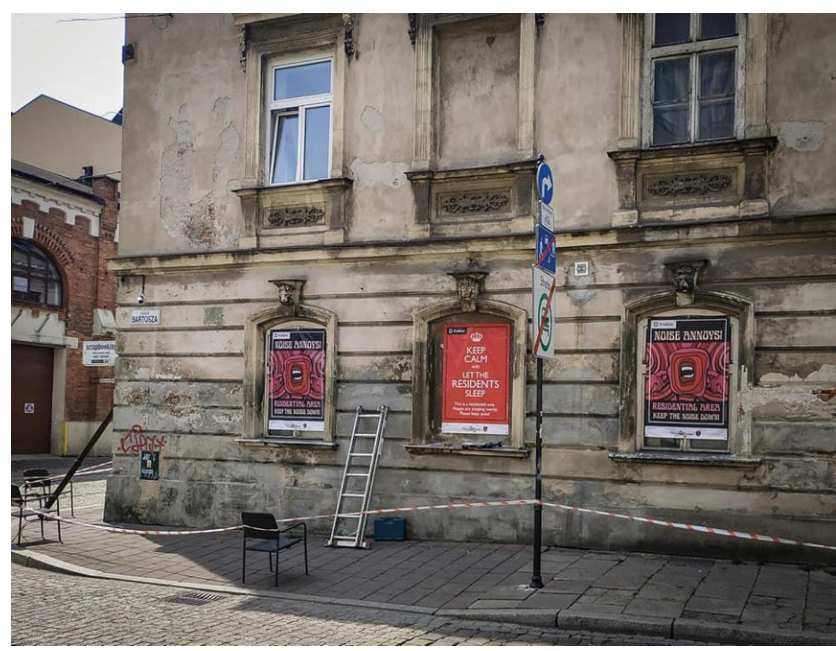

Fotografia 3. Plakaty informacyjne zawieszone w historycznej części Krakowa w 2019 r. Źródło: R. Pawlusiński

alkoholu jest łatwy dostęp do niego, rozumiany nie tylko w kategoriach przestrzennych, ale także cenowych. Cena alkoholu w placówkach handlowych jest znacznie niższa niż $\mathrm{w}$ pubach $\mathrm{i}$ innych obiektach gastronomicznych, co pozwala na jego częstszą i znacznie większą konsumpcję. Dopiero w połowie 2019 r. osiaggnięto kompromis w tej sprawie, jednak nie został on oparty na decyzji władz miasta, ale stanowił odpowiedź lokalnych przedsiębiorców na oczekiwania mieszkańców. Mowa tutaj o zawartym 2 września 2019 r. porozumieniu "Krakowskie porozumienie - dobre praktyki w zakresie odpowiedzialnej sprzedaży", wedle którego lokalni przedsiębiorcy mieli wyłączyć sprzedaż alkoholu w sklepach między godziną 24:00 a 5:30. Do porozumienia przystąpiło około 150 placówek, a jego realizację zaplanowano na okres jednego roku.

Mieszkańcy Kazimierza w celu uzyskania większego wpływu na władze miasta założyli w połowie $2019 \mathrm{r}$. grupę społecznościową na portalu Facebook pod nazwą „Dobra Noc Kraków”. Jak piszą:

[...] celem grupy jest ustalenie kroków jakie można (należy) podjacć, aby określić poziom hałasu i w dalszym kroku zredukować go do dopuszczalnych norm. [...] aby każdy mieszkaniec Krakowa był świadomy swoich praw i miał możliwość skutecznej ochrony. Dalszym celem jest zmobilizowanie władzy wykonawczej do egzekwowania prawa dotyczącego hałasu bez konieczności udziału mieszkańców („Dobra Noc Kraków”, 2019).

Grupa ta stała się forum wymiany informacji na temat możliwości egzekwowania prawa. Ostatecznie przekształciła się formalnie w Stowarzyszenie Dobra Noc Kraków.

Protesty mieszkańców spotkały się z reakcją ze strony władz miasta. W 2018 r. Kraków był organizatorem ważnej konferencji w ramach projektu Miasta Historyczne 3.0, której temat przewodni brzmiał „Mieszkańcy a odwiedzający - w poszukiwaniu jakości i komfortu". Jeden z jej paneli dyskusyjnych został poświęcony kwestiom zarządzania gospodarką nocną. W czerwcu 2019 r. na wniosek radnych miejskich przegłosowano uchwałę kierunkowa, skierowaną do Prezydenta Miasta Krakowa w sprawie powołania w mieście Komisji Burmistrza Nocnego (unieważniona przez Wojewodę Małopolskiego) (Uchwała, 2019). Od końca 2019 r. $\mathrm{w}$ ramach urzędu miejskiego działa nieformalny zespół (tzw. Okrągły Stół), który podejmuje problem zarządzania dziedzictwem kulturowym historycznej części Krakowa w warunkach turystyfikacji. Jednym $\mathrm{z}$ widocznych efektów prac tego zespołu była znaczna intensyfikacja aktywności służb miejskich i policji w porze nocnej. Podejmowano także próby ograniczenia bardzo uciążliwego, z punktu widzenia mieszkańców, zjawiska pub crawlingu, polegającego na odbywaniu grupowych wycieczek nocnych pomiędzy pubami, połączonych z konsumpcją alkoholu w każdym z nich.

Przedstawione powyżej działania nie wyeliminowały negatywnych następstw nadmiernego rozwoju gospodarki nocnej ani znacząco nie ograniczyły jej uciążliwych skutków. Proces ten jest długofalowy i wymaga konsekwentnych działań przy zaangażowaniu wielu podmiotów lokalnych, w tym władz miasta, służb miejskich, przedstawicieli sektora turystycznego i gastronomicznego, mieszkańców i lokalnych liderów opinii. Pierwsze sygnały postępu w tej kwestii są już obserwowane. Mieszkańcy zgłaszają na forach zmianę nastawienia właścicieli lokali do problemu hałasu. Pojawiają się również sygnały, że efekty przynosi akcja plakatowa, nawołująca turystów do zachowania ciszy nocnej. Szansę na złagodzenie omawianych problemów, przynajmniej w jakiejś części, dają także nowe projekty planowane przez Urząd Miasta Krakowa. Na szczególną uwagę zasługuje uruchomienie projektu (od maja 2020 r.) tzw. street workersów, których 
zadaniem będzie dążenie do minimalizacji hałasu oraz potencjalnych napięć między uczestnikami życia nocnego w tzw. hot spotach. Pomysł ten został skutecznie wdrożony w Amsterdamie.

\section{UWAGI KOŃCOWE}

W miastach we współczesnym świecie zachodzi wiele zmian o charakterze przestrzennym i funkcjonalnym. Ważne miejsce $\mathrm{w}$ tym względzie zajmuje gospodarka nocna i powiązana z nią koncepcja miasta $24 \mathrm{~h}$, czyli dostępnego (aktywnego) przez całą dobę. Jej istotą jest rozszerzanie aktywności społecznej i gospodarczej miasta na porę wieczorną i nocną, głównie w celu zwiększenia siły konkurencyjnej miasta (Lovatt, O'Connor, 1995; Shaw, 2020). Proces ten jest charakterystyczny zarówno dla miast globalnych (np. Londyn, Nowy Jork, Paryż), które funkcjonują jako centra światowego biznesu, jak i mniejszych ośrodków, które dysponują unikatowym dziedzictwem historycznym i/lub których rozwój opiera się na funkcjach kulturalnych, akademickich, turystycznych czy handlowych.

Rozwój gospodarki nocnej, chociaż postrzegany jest głównie w kategoriach korzyści, może rodzić wiele negatywnych następstw. Aktualna polityka miejska w sferze zarządzania nocą powinna uwzględniać złożony charakter tego zjawiska i dążyć do eliminacji niepożądanych skutków, zwłaszcza wobec mieszkańców. Istotne jest jednak pytanie, wpisane w słynne „prawo do miasta", czy miasto jest tylko dla mieszkańców, czy także dla gości (por. Kotus, 2015; Kowalczyk-Anioł, Zmyślony, 2017). Patrząc z punktu widzenia wszystkich użytkowników miasta celowe jest dążenie jego włodarzy, do równoważenia interesów obu tych grup.

Niewątpliwie w przypadku krakowskiego Kazimierza gospodarka nocna odegrała niebagatelny wpływ na rozwój dzielnicy w ciągu ostatnich dwóch dekad. Niestety przeważająca część obiektów NTE na Kazimierzu wciąż ogranicza swoją ofertę do sprzedaży alkoholu. Ten etap rozwoju zagraża obecnie stabilności lokalnego układu społeczno-gospodarczego. Zdaniem autorów poziom krytyczny został już osiągnięty i konieczne jest odejście od modelu prostej rozrywki nocnej na rzecz jej nowych form. W kształtowaniu oferty nocnej Kazimierza powinno się większą uwagę położyć na kwestie kulturowe i na tej podstawie dążyć do rozwoju produktów nocnych, bazujących na kulturze wysokiej. Dalsze podążanie ścieżką prostej rozrywki alkoholowej może prowadzić do konieczności stosowania agresywnej polityki cenowej, w związku z „zagrożeniem” ze strony sąsiednich ośrodków miejskich, np. Lwowa, które przyjęły podobny kierunek rozwoju. W przypadku Krakowa celowe wydaje się ukierunkowanie działań na pozyskanie turysty typu premium (Kruczek, Walas,
Chromy, 2019). Instrumentem sprzyjającym dokonaniu tych zmian wydaje się planowane utworzenie na obszarze Kazimierza parku kulturowego.

\section{BIBLIOGRAFIA}

Ashworth, G.J., Tunbridge, J.E. (2000). The tourist-historic city. London: Routledge.

Ashworth, G.J., Tunbridge J.E. (2004). Whose tourist-historic city? Localizing the Gobal and globalizing the local. W: A. Lew, M. Hall, A. Williams (red.), A Companion to Tourism. MaldenOxford-Carlton: Blackwell Publishing.

Bianchini, F. (1995). Night cultures, night economies. Planning Practice \& Research, 10 (2), 121-126.

Campo, D., Ryan, B.D. (2008). The entertainment zone: Unplanned nightlife and the revitalization of the American downtown. Journal of Urban Design, 13 (3), 291-315. https:// doi.org/10.1080/13574800802319543

Chatterton, P. (2002). Governing nightlife: Profit, fun and (dis) order in the contemporary City. Entertainment Law, 1 (2), 23-49. https://doi.org/10.1080/14730980210001730411

Cohen-Hattab, K. (2004). Historical research and tourism analysis: The case of the tourist-historic city of Jerusalem. Tourism Geographies, 6 (3), 279-302.https://doi.org/10.1080/1461668042000249629

„Dobra Noc Kraków" (2019). Pobrane z: https://www.facebook.com/ groups/dobranockrakow (11.10.2019).

Działek, J., Murzyn-Kupisz, M. (2015). Zachowania i preferencje przestrzenne młodych artystów w mieście na przykładzie Krakowa i Katowic. W: P. Trzepacz, J. Więcław-Michniewska, A. Brzosko-Sermak, A. Kołoś, Miasto w badaniach geografów. T. 1 (s. 91-120). Kraków: Instytut Geografii i Gospodarki Przestrzennej Uniwersytetu Jagiellońskiego w Krakowie.

Faracik, R. (2017). Sandomierz - miasto historyczne jako ośrodek turystyki. Turyzm, 27 (2), 35-44. https://doi. org/10.18778/0867-5856.27.2.03

Grochowicz, M. (2019). Konflikty przestrzenne wokół placu Nowego na krakowskim Kazimierzu. W: Ł. Fiedeń, K. Anielska, (red.), Wspótczesne problemy i kierunki badawcze w geografii. T. 7 (83-102). Kraków: Instytut Geografii i Gospodarki Przestrzennej Uniwersytetu Jagiellońskiego w Krakowie.

Hadfield, P., Lister, S., Traynor, P. (2009). This town's a different town today. Policing and regulating the night-time economy. Criminology \& Criminal Justice, 9 (4), 465-485. https://doi. org/10.1177/1748895809343409

Iwanicki, G., Dłużewska, A. (2015). Potential of city break clubbing tourism in Wrocław. Biulletin of Geography. Socioeconomic Series, 28, 77-90. https://doi.org/10.1515/bog-2015-0017

Iwanicki, G., Dłużewska, A. (2018). Party space in Cracow and Warsaw: Partying and conflicts. Economic Problems of Tourism, 4, 139-145. https://doi.org/10.18276/ept.2018.4.44-11

Kotus, J. (2015). Turyści w strukturze miast: obraz konfliktu czy koegzystencji? - rozważania na podstawie badań city users w dwóch miastach. Rozwój Regionalny i Polityka Regionalna, 31, 33-46. https://doi.org/10.14746/rrpr.2015.31.04

Kowalczyk-Anioł, J. (2019). Hipertrofia turystyki miejskiej - geneza i istota zjawiska. Konwersatorium Wiedzy o Mieście, 32 (4), 7-18. https://doi.org/10.18778/2543-9421.04.01

Kowalczyk-Anioł, J., Zmyślony, P. (2017). Turystyka miejska jako źródło protestów społecznych: przykłady Wenecji i Barcelony. Turystyka Kulturowa, 2, 7-36.

Kruczek, Z., Walas, B., Chromy, J. (2019). Od euforii do irytacji. Analiza postaw mieszkańców Krakowa, hotelarzy i restauratorów wobec dalszego rozwoju turystyki. W: M. Zowiosło, 
J. Kosiewicz, Sport i turystyka w perspektywie nauk społecznych: tradycje i wspótczesność (s. 287-298). Kraków: Akademia Wychowania Fizycznego.

Kursa, M. (2019). Nadchodzi nocny burmistrz Krakowa. Czym sie zajmie?. Pobrane z: https://krakow.wyborcza.pl/krakow/7,44 425,24824816,nadchodzi-nocny-burmistrz-krakowa-czym-sie-zajmie.html (11.10.2019).

van Liempt, I., van Aalst, I., Schwanen, T. (2015). Introduction: Geographies of the urban night. Urban Studies, 52 (3), 407-421. https://doi.org/10.1177/0042098014552933

London at night: An evidence base for a 24-hour city (2018). GLA Economics, London. Pobrane z: https://www.london.gov.uk/ sites/default/files/london-at-night-full-final.pdf (11.10.2019).

Lovatt, A., O'Connor, J. (1995). Cities and the night-time economy. Planning Practice \& Research, 2 (10), 127-134. https://doi. org/10.1080/02697459550036676

Mika, M. (red.) (2011), Kraków jako ośrodek turystyczny. Kraków: Instytut Geografii i Gospodarki Przestrzennej Uniwersytetu Jagiellońskiego w Krakowie.

Mikulska, P. (2018). Nowy pomyst Trzaskowskiego. "Nocny burmistrz", który kontroluje Warszawę. Pobrane z: https://wiadomosci.wp.pl/nowy-pomysl-trzaskowskiego-nocny-burmistrz-ktory-kontroluje-warszawe-6283322663995009a (11.10.2019).

Mróz, K. (2019). Geograficzne aspekty funkcjonowania gospodarki nocnej w miastach historycznych na przykładzie krakowskiego Kazimierza. Praca dyplomowa napisana pod kierunkiem dr R. Pawlusińskiego w Instytucie Geografii i Gospodarki Przestrzennej Uniwersytetu Jagiellońskiego w Krakowie.

Murzyn, M. (2006). Kazimierz. Środkowoeuropejskie doświadczenie rewitalizacji. Kraków: Międzynarodowe Centrum Kultury.

Murzyn-Kupisz, M. (2008). Przywracanie pamięci czy masowa konsumpcja? Dylematy odkrywania żydowskiego dziedzictwa kulturowego krakowskiego Kazimierza. W: M. Murzyn-Kupisz, J. Purchla (red.), Przywracanie pamięci. Rewitalizacja zabytkowych dzielnic żydowskich w miastach Europy Środkowej (s. 363-398). Kraków: Międzynarodowe Centrum Kultury.

Nofre, J., Giordano, E., Eldridge, E., Martins, J.C. (2017). Tourism, nightlife and planning: Challenges and opportunities for community liveability in La Barceloneta. Tourism Geographies, 3 (20), 377-396. https://doi.org/10.1080/14616688.2017.1375972

Nofre, J., Martins, J.C., Vaz, D., Fina, R., Sequera, J., Vale, P. (2018). The "Pink Street" in Cais do Sodré: Urban change and liminal governance in a nightlife district of Lisbon. Urban Research E Practice, 12 (4), 1-19. https://doi.org/10.1080/17535069.201 8.1449010

Pawlusiński, R., Kubal, M. (2011). Tradycje turystyczne Krakowa. W: M. Mika (red.), Kraków jako ośrodek turystyczny (s. 35-56). Kraków: Instytut Geografii i Gospodarki Przestrzennej Uniwersytetu Jagiellońskiego w Krakowie.

Pawlusiński, R., Kubal-Czerwińska, M. (2018). A new take on an old structure? Creative and slow tourism in Krakow (Poland). Journal of Tourism and Cultural Change, 16 (3), 265-285. https:// doi.org/10.1080/14766825.2017.1330338

Pawlusiński, R., Zmyślony, P. (2018). Gospodarka nocna a oferta kulturowa miast. Turystyka Kulturowa, 7, 7-22.

Pinke-Sziva, I., Smith, M., Olt, G., Berezvai Z. (2019). Overtourism and the night-time economy: A case study of Budapest.
International Journal of Tourism Cities, 5 (1), 1-16. https://doi. org/10.1108/IJTC-04-2018-0028

Radkowski, M. (2019). Ma go Paryż i Amsterdam. Warszawa czeka na nocnego burmistrza. Co będzie robit? Pobrane z: https:// warszawa.wyborcza.pl/warszawa/7,54420,25482441,ma-go-paryz-i-amsterdam-warszawa-czeka-na-nocnego-burmistrza. html (11.10.2019).

Roberts, M. (2006). From „creative city” to „no-go areas”: The expansion of the night-time economy in British town and city centres. Cities, 23 (5), 331-338. https://doi.org/10.1016/j. cities.2006.05.001

Roberts, M., Eldridge, A. (2009). Planning the night-time city. New York: Routledge.

Rowe, D. (2008). Culture, sport and night-time economy. International Journal of Cultural Policy, 14 (4), 399-415. https:// doi.org/10.1080/10286630802445864

Salamon, P. (2019). W Krakowie będzie nocny burmistrz. Pobrane z: https://lovekrakow.pl/aktualnosci/w-krakowie-bedzie-nocny-burmistrz_31081.html (11.10.2019).

Seijas, A., Gelders, M.M. (2020). Governing the night time city: The rise of night mayor as a new form of urban governance after dark. Urban Studies, 58 (2), 1-19. https://doi. org/10.1177/0042098019895224

Shaw, R. (2014). Beyond night-time economy: Affective atmospheres of the urban night. Geoforum, 51 (1), 87-95. https:// doi.org/10.1016/j.geoforum.2013.10.005

Shaw, R. (2020). Geographies of the night. International Encyclopedia of Human Geography, Second Edition, 6, 83-87. https://doi.org/10.1016/B978-0-08-102295-5.10187-8

Sheard, L. (2011). Anything could have happened: Women, the night-time economy, alcohol and drink spiking. Sociology, 45 (4), 619-633. https://doi.org/10.1177/0038038511406596

Think night: London`s neighbourhoods 6PM to 6AM. London night time commision. Pobrane z: https://www.london.gov. uk/sites/default/files/think_night___londons_neighbourhoods_from_6pm_to_6am.pdf (11.10.2019).

Tymczak, P. (2019). Kraków. Prezydentowi ma pomagać nocny burmistrz. Zobacz, jak wygląa nocne życie w mieście. Pobrane z: https://dziennikpolski24.pl/krakow-prezydentowi-ma-pomagac-nocny-burmistrz-zobacz-jak-wyglada-nocne-zycie-w-miescie-zdjecia/ar/c1-14144189 (11.10.2019).

Uchwała Rady Miasta Krakowa z 26 czerwca 2019 r. w sprawie ustalenia kierunków dziatania dla Prezydenta Miasta Krakowa w zakresie powołania Komisji Nocnego Burmistrza. Nr XIX/389/19.

Więcław, J. (1997). Zmiany funkcji dzielnicy Kazimierz w Krakowie w świetle współczesnych przekształceń społeczno-gospodarczych. Folia Geographica. Series Geographica Oeconomica, XXIX-XXX, 125-147.

Zmyślony, P., Pawlusiński, R. (2020). Tourism and the night-time economy: The perspective article. Tourism Review, 75 (1), 194-197. https://doi.org/10.1108/TR-05-2019-0158

Artykuł wpłyną:

12 czerwca 2020

Zaakceptowano do druku:

21 grudnia 2020 